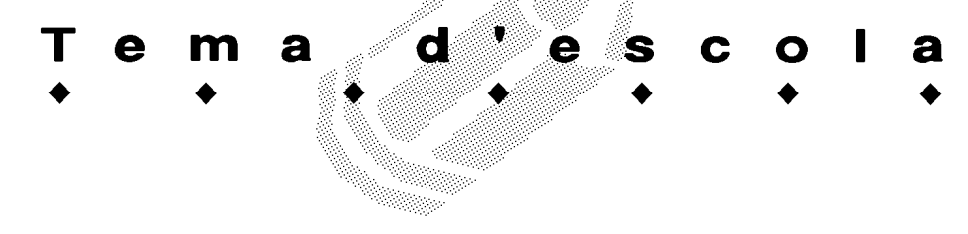

\title{
LA COMPETÈNCIA PER SER CIUTADÀ DEL SEGLE XXI I LA CONTRIBUCIÓ DE L'ESCOLA A LA SEVA ADQUISICIÓ
}

\author{
Luisa Girondo Pérez. Àrea de Didàctica de les Matemàtiques. URV
}

Quines són les capacitats, habilitats, coneixements, saber fer... què hauria de posseir un ciutadà del segle XXI en els països desenvolupats? Aquesta és, a grans trets, la pregunta que s'han fet organitzacions internacionals com l'OCEDE, la UNESCOi ila mateixa Unió Europea, que amb els seus informes intenten ajudar a prendre decisions en política educativa als governs dels diferents països.

Aquí a Catalunya, el terme competència també ha entrat amb força en el món escolar. Tot i que, de moment, es parla només de "competències bàsiques", segurament no som lluny d'un nou currículum que tingui el terme competència com a referència central.

Davant d'això, en aquest article ens proposem fer una síntesi tant de les fonts com de les interpretacions que es van donant al terme, i la repercusió que això pot tenir en la pràctica escolar.

\section{Les competències clau}

La preocupació dels organismes internacionals abans citats ha portat a la creació d'un grup d'investigació que tracta de definir el concepte de competència i postular quines serien les competències desitjables per als ciutadans. Evidentment, això no és una tasca senzilla, i no han faltat tampoc veus crítiques a l'excesiu protagonisme que l'economia, o els valors que imposa l'actual sistema econòmic, podria tenir en la definició d'aquestes competències. Per això s'ha abordat el tema de la selecció des d'unàmbit interdisciplinari i considerantels criteris d'investigadors en camps diversos. Al final s'ha acceptat l'existència d'unes competències necessàries o desitjables per a tots els ciutadans, que els permetin contribuir al seu benestar personal, econòmic i social (SIMONE, 2003), que quasi bé es podrien considerar com una extensió dels drets humans.

Per competència s'entén la capacitat i les habilitats que un individu posa en funcionament a l'hora d'enfrontar-se a tasques complexes. Per tant, és alguna cosa orientada a una demanda, a una tasca. Des d'un punt de vista més psicològic, podríem veure que l'estructura interna de la competència és una combinació d'habilitats pràctiques, de coneixements, de motivació, de valors étics, d'actituds, d'emocions i d'altres components socials i de comportament que es poden mobilitzar conjuntament per dur a terme, d'una manera eficaç, la tasca que es planteja.

A més d'aquesta descripció del terme, s'han formulat també les que es consideren, sota les perspectives formulades abans, les denominades competències clau o d'importancia primordial per als ciutadans. Per tenir una descripció àmplia de les raons que han portat a formular en síntesi tres grans blocs de competències clau, vegeu Simone (2003). Aquí en farem un breu resum.

1) La interacció en grups socialment heterogenis.

Es tracta de competències socials i interpersonals d'importància primordial per crear capital social. Se citen tres grans competències:

- Capacitat de relacionar-se bé amb altres persones (iniciar, mantenir i gestionar les relacions personals).

- Capacitat de cooperar i treballar en equip (les persones han de poder treballar juntes per assolir fites comunes).

- Capacitat de gestionar els conflictes i resoldre'ss (s'ha d'entendre que el conflicte és un aspecte intrínsec en les relacions personals, i que s'ha d'enfocar la seva gestió i resolució de forma constructiva).

2) La capacitat d'actuar de forma autònoma.

El concepte es refereix a la capacitat de les persones per desenvolupar i expressar un sentit d'elles mateixes, per exercir els seus drets i acceptar responsabilitats en els diferents àmbits de la vida. S'han identificat tres grans competències:

- Capacitat d'exercir els seus drets i capacitat de prendre responsabilitats (cada individu és una persona a la qual s'ha de tenir en compte en la família, com a ciutadà, com a treballador, com a consumidor...).

- Capacitat de formar i portar a terme plans de vida i projectes personals (les persones han de conceptualitzar i realitzar els objectius que donen sentit a les seves vides en conseqüència amb els seus propis valors).

- Capacitat d'actuar dins de la gran perspectiva d'un context més gran ( les persones han d'entendre com funciona un context més gran i com aquest els afecta per poder prendre decisions amb criteri). 


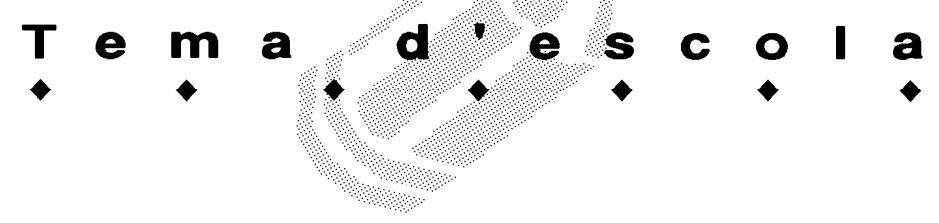

3) Habilitat per fer servir les eines de forma interactiva.

La paraula "eina" s'ha d'entendre en un sentit ampli. Les persones ens relacionem amb el nostre món a través d'eines cognitives, socials i físiques. Aquestes relacions constitueixen la manera com entenem el món i com ens fem competents amb la interacció. Per tant, una eina no es pot veure com un mediador passiu, sinó que és lintrument que permet que hi hagi un diàleg actiu entre la persona i el seu entorn. Les tres competències d'aquest bloc són :

- Capacitat de fer servir de forma interactiva el llenguatge i els símbols (capacitat de comunicació amb els altres i de desenvolupar coneixements i capacitats).

- Capacitat de fer servir de forma interactiva els coneixements i la informació (les persones han d'utilitzar els coneixements i la informació com a base per entendre opcions, formar opinions, prendre decisions i emprendre accions).

- Capacitat de fer senvir de forma interactiva la tecnologia (Habilitats tècniques per fer senvir les tecnologies i ser conscient de les noves formes d'interacció possibles amb l'ús de les noves tecnologies).

Totes aquestes competències clau estan interrelacionades, això vol dir que són importants en el seu conjunt. No s'ha de menystenir la dificultat que aquesta concepció de competències clau suposa a l'hora de pensar en el seu desenvolupament. Però així és la realitat, complexa, i no tenim altra via que la de tractar amb la complexitat. La vida moderna exigeix un alt nivell de complexitat mental, complexitat que implica un pensament més crític i que requereix un enfocament reflexiu i holístic per part de les persones.

\section{Les competències i la vida escolar}

Segons el que acabem de presentar, resulta obvi pensar que les fites de l'escolaritat amb perspectiva de competències clau van molt més enllà que recordar coneixements apresos, pensament abstracte i ser socialment integrat. En altres paraules, les habilitats bàsiques o tradiccionals són importants toti que no són suficients si es consideren els reptes complexos de la vida d'avui en dia. Però el que hi hagi una major exigència no vol dir que continguts, valors i actituds que tradicionalment persegueix l'escola no siguin un pilar essencial en la competència individual.

Ara tractarem de descriure com i en quins aspectes l'escola pot fer èmfasi en aquesta capacitació.

Les competències del bloc 1 són clarament competències de desenvolupament social a les quals l'escola, dintre de les seves posibilitats, posa el seu esforç. Relacionar-se amb els companys, treballar en equip i iniciar-se en la gestió de conflictes són cosa que l'escola pot fer. Naturalment, requerix una intencionalitat per part del professorat. Els alumnes no desenvoluparan la capacitat del treball en equip si mai no els fem treballar en grup; no adquiriran responsabilitat si el treball que els proposem és totalment guiat i no hi ha un marge per a la decisió, per al debat, per confrontar diferents punts de vista. Aquestes, juntament amb altres situacions d'interessos confrontats que surten amb freqüència en la vida escolar, són el marc idoni per iniciar-se en l'acceptació, valoració, solució i, en general, gestió de conflictes. Avui en dia s'accepta que els conflictes són inherents a la vida en societat; tractar d'analitzar-los i gestionar-los implica aprendre a viure en societat. Tractar únicament d'evitar-los és pensar en un món que ja no existeix.

Per al bloc 2 de competències caldria establir una línia d'actuacions que van des d'un treball sobre l'autonomia (amb alumnes més joves) a un treball sobre la responsabilitat, la maduració d'interessos i la capacitat de situar-se personalment en la societat que els envolta (alumnes més grans). També la forma de treballar a l'escola té molt a veure amb el desenvolupament d'aquestes capacitats, però en aquesta competència entren ja clarament molts aspectes de coneixements, actituds i valors que els alumnes van adquirint en la seves vides tant dintre com fora de l'escola.

El bloc 3 és clarament un bloc de desenvolupament escolar. Aquí està l'adquisició dels mediadors per interaccionar amb el món que els envolta. Mediadors que no tenen un paper passiu en aquesta interacció, sinó que són les "ulleres" que ens permeten veure i interpretar els diferents aspectes de la realitat. A l'hora que un alumne aprèn a expressar-se verbalment, desenvolupa habilitats cognitives i habilitats socials. A l'intentar aprendre com funcionen els números i per a què s'utilitzen socialment, està desenvolupant hablitats cognitives i habilitats de comunicació per entendre i produir informació per aquest mitjà.

Les diferents disciplines escolars no són més que diferents "vidres" que col-loquem en les nostres ulleres que ens permeten obsenvar, relacionar i, en una paraula, conèixer el nostre entorn físic i social. Aquest coneixement és el que ens capacita per prendre decisions assenyades, per entendre contextos més amplis, per ser conscients de les nostres decisions en àmbits personals, socials o de feina.

Aquesta hauria de ser la perspectiva amb la qual afrontar les tasques escolars. Pensar en els alumnes com a futurs ciutadans, que necessàriament s'enfontaran a una realitat complexa, per tractar la qual es necessiten capacitacions més exigents que fa un quart de segle i que, òbviament, com que l'escola no ho pot fer tot, caldrà fer un plantejament ajustat per optimitzar el temps i els recursos. Cal prioritzar coneixements, cal plantejar metodologies interactives, cal fer senvir les noves tecnologies que alhora permeten i exigeixen noves formes d'interaccionar.

\section{Referències bibliogràtiques}

SIMONE, D. La naturalesa de les competències clau. Una perspectiva interdisciplinària i internacional. Congrés de competències bàsiques. Generalitat de Catalunya. Departament d'Ensenyament. Barcelona. 26-27 juny 2003.

(www.gencat.net/ense/csda/congres/pdf/cas_conferencia1.pdf ). 